\title{
АРХЕОЛОГІЯ
}

УДК 904 (477.73)

DOI: https://doi.org/10.33782/eminak2019.1(25).208

\section{СТРУКТУРА ТА ХАРАКТЕР ПРИМІЩЕННЯ № 21 ГОРОДИЩА ДИКИЙ САД*}

\author{
Кирило Горбенко ${ }^{1}$ Олександр Смирнов ${ }^{2}$ \\ Миколаївський національний університет імені В.О. Сухомлинського (Миколаїв, Україна) \\ 1e-mail: dikiysad@ukr.net; ORCID: https://orcid.org/0000-0002-0510-3792 \\ 1e-mail: smyrnovl@ukr.net; ORCID: https://orcid.org/0000-0002-7849-3840
}

У статті розкрито особливості приміщення № 21, що розташовувалося на території «ближнього передмістя» городища доби фінального бронзового віку Дикий Сад у Миколаєві. Охарактеризовані архітектурна структура та принципи будови, а також особливості внутрішнього заповнення ям. Проаналізовано матеріальні предмети (керамічний посуд, вироби з кістки, рогу, глини, каменю, бронзи), що зафіксовано у культурному шарі. Встановлено, що приміщення № 21 було господарсько-виробничою майстернею зі складною системою багатофункціональних ям (стовпові, господарські, виробничі, ритуальні).

Ключові слова: фінальний бронзовий вік, городище Дикий Сад, білозерська культура, матеріальні предмети, артефакти

В історичному центрі сучасного Миколаєва розташоване давне городище, що отримало сучасну назву - Дикий Сад. У культурно-хронологічному аспекті воно відноситься до білозерської археологічної культури доби фінальної бронзи (XIII/XIIXII/XI cт. до н.е.). За результатами радіо-вуглецевого датування $\left(\mathrm{C}^{14}\right)$ діапазон існування городища становить 1186-925 рр. до н.е.

Під час свого існування городище Дикий Сад займало високий мис стрімчастого краю плато при злитті річок Південний Буг та Інгул. Мис з боку степу захищався ярами та двома ровами між ними. Загальна площа збереженої території сягає понад 4,0 га.

Городище побудоване у формі овалу, витягнутого по вісі Пд-С-Пн-З. За конструктивними особливостями воно складалося з огородженої ровом «цитаделі», «передмістя» та «посада», який розташовувався за зовнішнім ровом (рис. 1). Архітектурні споруди розташовувалися рядами уздовж річки Інгул і практично примикали один до одного, створюючи єдиний архітектурний комплекс.

Городище відкрито у 1927 р. Камінським Феодосієм Тимофійовичем, а перші фрагментарні дослідження проведено у 1956р., археологічною експедицією під керівництвом Славина Лазаря Мойсейовичаํํ. Регулярні розкопки на території горо-

\footnotetext{
1 Горбенко К.В. Начальный этап археологических исследований городища Дикий Сад // Емінак. 2017. № 3 (19) (липень-вересень). Т. 2. С. 9-25.
} 
дища розпочаті Гребенниковим Юрієм Спиридоновичем на початку 1990-х років і тривають до сьогодення під керівництвом Горбенка Кирила Володимировича22.

У ході регулярних розкопок пам'ятки досліджено залишки архітектурних споруд (житлові, господарські, ритуально-культові й оборонні об'єкти); зафіксовано різноманітні артефакти (керамічний посуд, бронзові, кістяні та кам'яні предмети, вироби з рогу та глини) ${ }^{3}$; проведені комплексні аналізи матеріалів із застосуванням новітніх методів природничих наук 4 . У результаті проведених досліджень накопичено багато нових даних, що змінили уявлення про цю пам'ятку та дозволили не тільки по-іншому подивитися на історичний розвиток регіону Степового Побужжя, але й на характер і культурну спадщину усієї білозерської культури Північного Причорномор'я5.

У 2016-17 роках археологічною експедицією Миколаївського національного університету досліджено новий археологічний об'єкт на території городища Дикий Сад - приміщення № 21.

У запропонованій статті надається загальна характеристика основних показників приміщення № 21, розкриваються його архітектурні особливості, характер внутрішнього заповнення ям, аналізуються матеріальні предмети (керамічні посудини, предмети виготовлені з глини, каменю, рогу та бронзи).

Приміщення № 21 розташовувалося на території «ближнього передмістя» городища, вздовж південної частини оборонного рову «цитаделі» (рис. 1).

Приміщення орієнтувалося практично за сторонами світу (схід-захід-північпівдень) і мало розміри: 9,0х7,0 м із заглибленням у материк на 0,4-0,5 м (рис. 2). Перепад рівня підлоги становив орієнтовно 0,20 м (у західній частині 20,70-20,65 м; у східній - 20,50-20,45 м над рівнем моря). Ймовірно, при будівництві об'єкта жителі Дикого Саду враховували природній перепад денної поверхні та рівня виходу материкової глини (зниження із заходу на схід і з півдня на північ).

Характер і структура внутрішнього заповнення та розташування глинистих завалів дозволяють припустити, що три стіни приміщення (західна, східна та північна) були глинобитними з домішками середнього та мілкого вапняку, особливо яскраво це простежується у східній і західній частинах приміщення (завали, що складалися з понад сотні вапнякових каменів у кожній стіні). Східна стіна, по траверсу, виходила на західний фасад кам'яного фундаменту мосту через рів, що надавало додатковий захист проходу на територію «цитаделі» городища (рис. 1).

Південна стіна мала більш фундаментальну однофасадну кам'яну конструкцію, що складалася з великих рваних по слою вапнякових каменів (бут і плитняк розмірами 0,15-0,75x0,25-0,70x0,06-0,16 м) зі слабкими слідами обробки. Ширина

\footnotetext{
2 Горбенко К.В. Укріплене поселення (городище) епохи фінальної бронзи Дикий Сад у місті Миколаєві // Краєзнавство. 2018. № 1 (102). С. 6-20.

3 Горбенко К.В. Основные аспекты материальной культуры городища Дикий Сад // Емінак. 2016. № 4 (16) (жовтень-грудень). Спецвипуск: Forum Olbicum I. Пам’яті В.В. Крапівіної. С. 19-32.

4 Горбенко К.В., Пашкевич Г.О. Палеоетноботанічні дослідження на території городища Дикий Сад // Емінак. 2010. № 1-4 (5) (січень-грудень). С. 5-19; Горбенко К.В., Гошко Т.Ю. Металеві вироби 3 поселення Дикий Сад // Археологія. 2010. № 1. С. 97-111.; Гошко Т.Ю., Агапов С.О., Отрощенко В.В. Металеві казани з Великого Степу за доби пізньої бронзи. Київ, 2018. С. 96-104.

5 Отрощенко В.В. Укріплене поселення «Дикий Сад» в системі пам'яток білозерської культури // Емінак. 2008. № 1-4 (3) (січень-грудень). С. 5-10; Черняков I.Т. «Дикий Сад», Гомер, Геродот, Троя, ахейці та кіммерійці (коментар одного археологічного відкриття в Україні) // Праці центру пам'яткознавства. 2010. № 17. С. 116-122.
} 
швів між камінням становила 0,04-0,08 м. Довжина кладки - 8,0 м, ширина - від 0,30 м до 1,75 м, висота - від 0,20 м до 0,60 м. У східній частині кладки камені поставлені на ребро, у західній - плазом, на земляному розчині. Кладка рядова (від одного до п’яті рядів), нижній ряд встановлено на материковому грунті (рис. 3-а, 3-б).

У верхньому ряду кладки (західна частина) камені мали округлі заглиблення, ймовірно, для встановлення дерев'яних стовпів, а східна частина кладки маркувала вхідний коридор до приміщення (рис. 2).

У західній частині кладки до фундаменту примикає прямокутна прибудова, що складається з 2-3 рядів каменів. Камені стоять на ребрах під кутом 45-50 , примикаючи один до одного. Розміри прибудови по краях зовнішнього ряду - 2,0х2,0 м (рис. 3-в). Усередині прибудови - дві стовпові ями № 15 і 16 (діаметром 0,25-0,35 м, глибиною 0,05-0,08 м). На схід від неї півколом примикає ряд 35 каменів, за характером завалу яких можна зробити висновок, що вони утворювали якусь ступінчасту конструкцію, що упиралася у прямокутну прибудову (рис. 2).

Вірогідно, при будівництві фундаменту південної стіни використовували комбінований принцип кладки: у східній частині - цокольна конструкція; у західній - облицьована.

У західній частині приміщення, біля західної стіни, розташовувалося два плоских вапнякових каменя, що знаходилися на своєрідних постаментах з гумусу та дрібного вапнякового буту. Камінь середніх розмірів вмонтовано у структуру стіни під невеликим нахилом (відмітка 21,37-20,95 м), другий, більший, знаходився від нього по вісі південний захід-північний схід на відстані 0,25 м (відмітка 20,93 м) і розташовувався горизонтально. При цьому з правого боку від каменів, за рівнем підлоги, фіксувалося скупчення рогів оленя, кози та сайги, а також глини зеленого кольору. Виходячи з розташування каменів і скупчення відходів косторізного та гончарного виробництва, можна припустити, що це могло бути своєрідне робоче місце майстра (обробка рогів і виготовлення керамічного посуду).

У заповненні приміщення, серед артефактів, переважає фрагментований керамічний посуд, що представлений вінцями, стінками та донцями посудин. Закриті посудини (рис. 5) представлені горщиками різних типів, банкоподібними посудинами, келихами, корчагами (одна корчага 3 вертикальними ручками) (рис. 5: 42). Відкриті посудини представлені мисками (рис.6: 1-11) 3 прямими відігнутими стінками, пласким денцем великого діаметру (вінчики мисок заокруглені, переважно орнаментовані овальним та округлим вдавлюванням) і пласкими жаровнями (рис. 6: 12-15), частина жаровень з сегментно-обрізаним корпусом.

Формувальна маса груба, хоча зустрічаються фрагменти посуду із загладженою та лощеною структурою поверхні (10 фрагментів горщиків і келихів). Орнаментація посуду різноманітна (прокреслені лінії, пружки, овальні вдавлювання, округлий і зубчатий штамп, жолобки).

Кам'яні знаряддя праці (рис.9: 9-17) представлені курантами, грузиламиякорями, зернотеркою та предметами антропоморфної форми.

Вироби з кісток і рогів тварин (бик, сайга, коза, олень), представлені псаліями та їх заготовками, гарпуном, лощилом, знаряддям для нанесення орнаменту (рис. 9: 1-8).

Окремо треба наголосити на тому факті, що у заповненні приміщення (рівень підлоги) у великій кількості (понад 100 фрагментів) зафіксовано роги оленя, кози та сайги зі слідами обробки, а також кістки тварин (велика та дрібна рогата худоба, кінь, свиня) та риб (таблиця 1). 
На рівні підлоги приміщення зафіксовано 22 ями різної функціональної приналежності: 11 стовпових, 4 господарських, 1 господарсько-виробнича, 6 господарськоритуальних (рис. 2 та 4).

Стовпові ями (№ 1, 4, 7, 13, 15, 16, 17, 18, 19, 20, 22):

- Яма № 1 у плані округлої форми (діаметр 0,7 м, глибина 0,3 м). Верхнє заповнення - гумус темного кольору з домішкою суглинку (горілий грунт). На глибині 0,1 м від рівня впуску, у південній частині ями зафіксовано кістки тварин (лопатка та суглоб), вапняковий курант, кам'яне ковадло та невиразні фрагменти кераміки.

- Яма № 4 у плані овальної форми (0,5х0,6 м; глибина 0,25 м). Верхнє заповнення - суглинок світло-коричневого кольору (пробка). На глибині 0,05 м заповнення переходить у горілий грунт. В ямі зафіксовано дві щелепи тварини (собака?), невиразні фрагменти кераміки, кістки тварин і стулка раковини морського молюска.

- Яма № 7 у плані овальної форми (0,55х0,60 м; глибина 0,60 м). Верхнє заповнення - гумус чорного кольору з домішкою суглинку світло-коричневого кольору, керамічних фрагментів і вапняку (3 шт.). На глибині 0,25 м, у східній частині ями, зафіксовано дрібні каміння, кістки тварин, вапнякова плита трапецієвидної форми 3 обробленими гранями.

- Яма № 13 у плані округлої форми (діаметр 0,50 м, глибина 0,20 м, діаметр донної частини - 0,30 м). Заповнення ями однорідне - гумусовий суглинок темного кольору з керамічними фрагментами та дрібний вапняковий бут. Стінки ями глинисті, що плавно переходять у глинисте дно.

- Яма № 15 округлої форми, розташовувалася всередині кам'яної кладки західної частини південного муру приміщення (діаметр 0,25 м, глибина 0,05 м; діаметр донної частини - 0,1 м). Заповнення ями - гумусного суглинку сірого кольору. Стінки ями глинисті, плавно переходять у глинисте дно.

- Яма № 16 округлої форми, розташовувалася у середині кам’яної кладки західної частини південної стіни приміщення (діаметр 0,35 м, глибина 0,08 м). Заповнення ями - гумусний суглинок сірого кольору з вкрапленням глея. У заповненні - дві маловиразні стінки кераміки (горщик темного кольору) та кістка тварини (дрібна рогата худоба). Стінки глинисті, плавно переходять у глинисте дно.

- Яма № 17 округлої форми (діаметр 0,15 м, глибина 0,15 м; діаметр донної частини - 0,03 м). Заповнення ями - гумусний суглинок світло-коричневого кольору. Стінки глиняні, плавно переходять у глинисте дно.

- Яма № 18 округлої форми, розташовувалася біля західної стіни приміщення (діаметр 0,13 м, глибина 0,15 м; діаметр донної частини - 0,03 м). Заповнення ями гумусний суглинок сірого кольору. Її стінки глинисті, плавно переходять у глинисте дно.

- Яма № 19 округлої форми, розташовувалася практично у центрі приміщення (діаметр 0,20 м, глибина 0,12 м; діаметр донної частини - 0,08 м). Заповнення ями гумусний суглинок коричневого кольору та дрібний вапняковий бут. Стінки глинисті, плавно переходять у глинисте дно. Можливо, яма призначалася для встановлення центрального стовпа (опора для кріплення покрівлі приміщення).

- Яма № 20 округлої форми, розташовувалась у північно-західному куті приміщення (діаметр 0,80 м, глибина 0,25 м; діаметр донної частини - 0,50 м). Заповнення ями - гумусний суглинок коричневого кольору. У заповненні - фрагменти кераміки (стінка лощеного горщика коричневого кольору, вінчик миски, стінки від двох горщиків), кістки тварин (великої та дрібної рогатої худоби) і камінь (перепа- 
лений піщаник). Стінки глинисті, плавно переходять у глинисте дно конусоподібної форми. Можливо, яма призначалася для великого дерев'яного стовпу (кріплення покрівлі та північно-західного кута приміщення).

- Яма № 22 округлої форми (діаметр 0,45 м, глибина 0,15 м, діаметр донної частини 0,1 м). Навколо ями фіксувалося скупчення дрібного вапнякового каміння (залишки східної стіни приміщення). Верхнє заповнення - гумус темного кольору з невиразними фрагментами стінок горщика, дрібних кісток тварин і дрібного вапнякового буту. Стінки ями рівні, глинисті, плавно переходять у глинисте дно конічної форми. Можливо, яма призначалася для великого дерев'яного стовпу (підтримка крівлі та східної стіни приміщення).

Господарські ями (№ 2, 6, 9, 10):

- Яма № 2 у плані округлої форми (діаметр 0,7 м, глибина 0,9 м; дно - діаметр 1,1 м). Верхнє заповнення - гумус світло-коричневого кольору з домішкою суглинку, золистими вкрапленнями, вапняковим бутом (5 шт.), двома плитками ракушняка та дрібними кістками риби. На глибині 0,2-0,4 м, у східній частині ями зафіксовано великий вапняковий камінь (0,3х0,2x0,1 м), фрагменти кераміки, вапнякового буту, кісток тварин, глея, кременевий відщеп і фрагмент панцира черепахи.

- Яма № 6 у плані округлої форми (діаметр 0,55 м, глибина 0,75 м; дно - діаметр 0,80 м). Верхнє заповнення - гумус з домішкою суглинку світло-коричневого кольору (пробка). На глибині 0,35 м заповнення ями переходить у золистий грунт 3 дрібним вапняковим бутом (10шт.) і вкрапленнями глея. На глибині 0,50 м зафіксовано фрагменти кераміки, великий і дрібний вапняковий бут, курант та астрагал. На глибині 0,65-0,70 м заповнення переходить у горілий грунт з вкрапленнями глею, фрагментів керамічного посуду, кісток тварин і гальки. Один екземпляр гальки, можливо, використовувався в якості лощила для обробки рогів і кісток.

- Яма № 9 у плані округлої форми (діаметр 0,60 м, глибина 0,50 м; дно - діаметр 0,85 м). Верхнє заповнення - гумус темно-сірого кольору 3 домішкою світлокоричневого суглинку. На глибині 0,20 м, по всій площі ями, проявився горілий грунт, 3 керамікою та вапняковим бутом (16 шт.). На глибині 0,4-0,50 м грунт змінюється на гумус темного кольору. На цьому рівні зафіксовані фрагменти керамічного посуду, кістки тварин, кременевий відщеп і дрібний вапняковий бут (8 шт.).

- Яма № 10 у плані округлої форми (діаметр 0,55 м, глибина 0,45 м; дно - діаметр 0,6 м). Верхнє заповнення - гумус коричневого кольору з домішкою суглинку. На глибині 0,10-0,15 м - скупчення кісток тварин і хребців риби. На глибині 0,3 м проявився горілий грунт з фрагментами кераміки, глея та вапнякового буту (11 шт.).

\section{Господарсько-виробнича яма (№ 8):}

- Яма № 8 у плані овальної форми (0,55х0,60 м; глибина 0,75 м). Верхнє заповнення - гумус з домішкою суглинку світло-коричневого кольору. У східній частині ями (за рівнем впуску ями) пляма округлої форми (діаметр 0,1 м) відділена від основної частини ями глинистою стінкою (діаметр 0,02 м). Можливо, це отвір для сопла. На глибині 0,15 м ямка поєднувалася з основною ямою. На цій глибині, біля ямки, зафіксовано шматок шлаку. На глибині 0,65-0,75 м зафіксовано фрагменти керамічного посуду, вапнякового буту (10шт.), дві кістки тварин, курант і предмет 3 бронзи (пластина скручена у 1,5 оберти), можливо, фрагмент пронизки. На нижньому рівні ями (глибина 0,75 м) - округлий отвір (діаметром 0,1 м і глибиною 0,05 м), що співпадає за напрямком з верхнім отвором (можливо, отвори поєднувалися глиняним соплом). Вірогідно, яма призначалася для бронзоливарного виробництва. 
Господарсько-ритуальні ями (№ 3, 5, 11, 12, 14, 21):

- Яма № 3 в плані округлої форми (діаметр 0,5 м, глибина 0,25 м; дно - діаметр 0,6 м). Заповнення - горілий грунт з фрагментами керамічного посуду; фрагментом кістяної ритуальної накладки.

- Яма № 5 в плані овальної форми (0,55x0,65 м; глибина 0,65 м). Верхнє заповнення - гумус світло-коричневого кольору з домішкою суглинку. На глибині 0,25 м зафіксована повна заготівка для псалія з рогу сайги та щелеп тварини. На глибині 0,30 м зафіксовано два вапнякових каміння (один у формі антропоморфної стели), курант і фрагменти кераміки. На глибині 0,50-0,60 м зафіксовано вапняковий бут (65 шт.), дві частки великої вапнякової плити прямокутної форми з обробленими краями (антропоморфна стела), фрагменти кераміки, кістки тварин і риби.

- Яма № 11 в плані округлої форми (діаметр 0,60 м, глибина 0,65 м; дно - діаметр 0,8 м). Верхнє заповнення - гумус чорного кольору та вапняковий бут (20 шт.). На глибині 0,40 м, у західній частині ями, велика вапнякова плита - фрагмент антропоморфної стели. Під стелою - горілий грунт, кераміка, кістки тварин, рибні кістки та луска. На глибині 0,60 м зафіксовані: предмет з хребця тварини (котушка), фрагмент прясельця, фрагмент панцира черепахи.

- Яма № 12 в плані округлої форми (діаметр 0,60 м, глибина 0,95 м; дно - діаметр 0,85 м). Верхнє заповнення - гумус з домішкою суглинку світло-коричневого кольору. На глибині 0,50 м проявився горілий грунт товщиною 0,1 м (перший прошарок). На глибині 0,60-0,75 м яма забита вапняковим камінням (45 шт.) та керамікою (ручка лощеного черпака з'єдналася з фрагментом ручки з ями № 11). На глибині 0,80 м проявився горілий грунт товщиною 0,15 м (другий прошарок). На глибині 0,85 м зафіксовано частину вапнякової плити (уламок з'єднався з фрагментом антропоморфною стели з ями № 11). Під плитою - скупчення горілих кісток тварин; риби та три річкові мушлі.

- Яма № 14 в плані округлої формі (діаметр 0,60 м, глибина 0,55 м, діаметр донної частини - 0,70 м). Верхнє заповнення - гумусовий суглинок коричневого кольору 3 невиразними фрагментами керамічних стінок і дрібних кісток риби. На глибині 0,20 м, у північно-східній частині ями зафіксований камінь-ракушняк антропоморфної форми та деревне вугілля. Під камінням, з північної частини ями, на глибині 0,25 м, зафіксована вапнякова плитка з обробленими краями. Аналогічні плитки фіксувались в ямах № 7 і 12.

На глибині 0,35 м проявився горілий грунт. На цьому рівні зафіксовані фрагменти керамічного посуду (горщик келихоподібної форми з валиком і миска з орнаментом - округлі вдавлювання по вінчику, насічки та вдавлювання на внутрішній частині вінчика), рибні кістки, вапняковий бут і фрагменти панцира черепахи.

На глибині 0,40 м, у північній частині, зафіксований кам'яний предмет з чорного базальту циліндричної форми - розтиральник і кістки дрібної рогатої худоби. На глибині 0,45-0,50 м, у південній частині ями, фрагменти керамічного горщика з валиком, великий шматок глини зеленого кольору (глей) та обгорілі зерна. Ближче до донної частини яма розширюється. Стінки ями глинисті та плавно переходять у рівне та прожарене дно.

- Яма № 21 округлої форми (діаметр 0,55 м, глибина 0,65 м; діаметр донної частини - 0,90 м). Верхнє заповнення - гумусний суглинок коричневого кольору та рибні хребти (сом). На глибині 0,15-0,20 м, у східній частині ями, зафіксовані трубчасті кістки тварин, ребра та надп'яткова кістка (astragalus) (велика та дрібна рогата 
худоба, свиня, ріг оленя) і дрібний вапняковий бут. На глибині 0,25 м грунт переходить у золотисте заповнення. На рівні 0,25-0,30 м зафіксована права щелепа тварини (можливо, собака) та фрагменти керамічного посуду. На глибині 0,35 м зафіксований вапняковий камінь і фаланга пальця людини (?). 3 цього рівня (0,35 м) яма по всій площині забита дрібним і середнім вапняковим камінням (15 шт.). Кам'яний завал простежується до рівня 0,60 м глибини ями. Серед каменів, на глибині 0,45-0,50 м, у східній частині ями зафіксована кістка коня та панцир черепахи. У південній частині ями - фрагменти керамічного посуду та курант. Стінки глинисті, плавно переходять у глинисте просушене дно.

Отже, серед ям приміщення переважали стовпові, що відрізнялися за розміром і глибиною. Частина стовпових ям (№ 15, 16, 17, 18, 19), призначалася для встановлення невеликих стовпів (діаметр 0,15-0,35 м, глибина 0,05-0,15 м). Друга частина (№ $1,4,7,13,20,22)$, призначалася для встановлення більш масивних стовпів (діаметр 0,50-0,80 м, глибина 0,15-0,60 м), що використовувалися для кріплення стін і даху приміщення.

Інші ями, можливо, розподілити на наступні групи:

- господарські (№ 2, 6, 9, 10), що мали діаметр 0,50-0,70 м, глибину 0,45-0,90 м і використовувалися для зберігання продуктів (риби та м'яса);

- господарсько-виробничу (№ 8), що мала складну конструкцію та використовувалася, ймовірно, для певного виробництва (зокрема, бронзоливарного);

- господарсько-ритуальні (№ 3, 5, 11, 12, 14, 21), що мали діаметр 0,55-0,60 м, глибину 0,55-0,95 м і використовувалися у господарстві для зберігання харчів, але їх заповнення мало й риси певних культових дій, своєрідних ритуальних підношень богам (забутовка вапняковим камінням, горілий грунт і зерна, антропоморфні плити та стели, панцирі черепахи, окремі господарські речі (заготівка псалія), зокрема, ритуальна накладка, котушка, керамічне прясельце, розтиральник з чорного базальту).

У заповненні ям, серед артефактів переважає фрагментований керамічний посуд, що представлено вінцями, стінками та донцями посудин. Закриті посудини (рис. 7) представлені горщиками різних типів, посудинами банкоподібної форми, келихами, черпаками та корчагами. Відкриті посудини (рис. 8) представлені мисками (рис. 8: 15) $з$ прямими відігнутими стінками, пласким денцем великого діаметру (вінчики мисок заокруглені, переважно орнаментовані овальним та округлим вдавлюванням) і пласкими жаровнями (рис. 8: 6-7), частина з них має сегментно-обрізаний корпус.

Формувальна маса груба, окремо зустрічаються фрагменти посуду з загладженою та лощеною структурою поверхні (15 фрагментів горщиків, келихів і черпаків). Лощені фрагменти переважають у господарсько-ритуальних ямах (таблиця 1). Орнаментація посуду різноманітна (прокреслені лінії, пружки, овальні вдавлювання).

Кам'яні знаряддя праці (рис. 10: 1, 2, 4, 6-9, 11-13, 15-17, 21-27) представлені курантами, ковадлами, лощилом, антропоморфними стелами, розтиральниками з чорного базальту (рис. 10: 11, 26).

Вироби з кісток і рогів тварин (бик, сайга, коза, олень), представлені ритуальною накладкою, заготівкою для псалія та котушкою (рис. 10: 3, 5, 19).

Інші артефакти представлені фрагментом бронзової скрученої пластини (рис. 10: 14) і керамічним прясельцем (рис. 10: 20).

Серед кісток тварин переважають фрагменти великої та дрібної рогатої худоби, 
риб, зустрічаються окремі кістки коня, свині, а також мушлі, панцирі черепахи (таблиця 1) й астрагали (рис. 10: 10, 18).

Усі артефакти, що зафіксовані у заповненні та ямах приміщення, є характерними для колекції матеріальних предметів Дикого Саду та відносяться до начального етапу білозерської археологічної культури.

\section{Висновки}

Отже, приміщення № 21, злегка заглиблене, прямокутної форми з овальними кутами, довгою віссю витягнуто уздовж річки (площа 63 м²). Три стіни були глинобитні, 3 домішками вапнякового буту (понад 100 одиниць у кожній), кераміки та кісток тварин і риби. Південна стіна мала кам'яний фундамент із системою кладки, характерною, як для сабатинівської, так й для білозерської систем домобудівництва6

Вхід до приміщення у формі коридору (ширина 0,7-0,75 м, довжина 1,25-1,75 м) 3 невеликим нахилом, розташовувався у південно-східному куті. Дах, виходячи з розташування стовпових ям, був односкатним, з нахилом до оборонного рову. Підлога добре утрамбована та промазана глинистим розчином багато разів.

Виходячи $з$ конструктивних особливостей побудови приміщення, характеру та заповнення ям, а також зафіксованих артефактів та екофактів, можна припустити, що воно використовувалося мешканцями городища як житло та господарськовиробнича споруда (косторізна майстерня) зі складною системою багатофункціональних ям (стовпові, господарські, господарсько-виробничі, господарськоритуальні).

Подібні споруди є характерними для пам'яток Північного-Західного Причорномор'я доби пізньої та фінальної бронзи7.

Основу колекції матеріальних предметів, зафіксованих на рівні підлоги та заповненні ям приміщення, складає керамічний посуд (232 фрагмента), що можна розподілити на дві групи: закриті (183 фрагменти) та відкриті (49 фрагментів) (таблиця 1).

Закриті посудини, репрезентовані переважно горщиками (73\%), трьох типів: 3 відігнутими вінцями та дугоподібною у перетині шийкою з найбільшим розширення у верхній третині тулуба; з прямою шийкою, відігнутим вінцем і максимальним розширенням тулуба у середній частині; з конусоподібною шийкою та максимальним розширенням тулуба у середній частині. Орнаментовані овальним та округлим вдавлюванням; пружками з незамкнутими кінцями; орнаментованими пружками (косі вдавлювання). Формувальна маса: груба з домішками жорстви та кварцового піску, у перетині - однорідного сірого, коричневого та чорного кольору. Зовнішня поверхня коричневого, сірого або чорного кольору; внутрішня - темно-сірого, чорного та темно-коричневого кольору.

Келихи складають другу, за кількістю фрагментів, групу серед закритих посудин (19\%). Серед них зустрічаються фрагменти приземкуватих келихів з циліндричною та дугоподібною шийкою (з лощінням і без) та келихів витягнутих пропорцій 3 циліндричною шийкою (з лощінням і без). Келихи орнаментовані вертикальними прокресленими лініями; прокресленими лініями у формі трикутників, вертикаль-

\footnotetext{
6 Березанская С.С., Отрощенко В.В., Чередниченко Н.Н., Шарафутдинова И.Н. Культуры эпохи бронзы на территории Украины. Киев: Наукова думка, 1986. С. 88-91, 121-125.

7 Ванчугов В.П. Белозерская культура в Северо-Западном Причерноморье. Проблема формирования белозерской культуры. Киев: Наук. думка, 1990. С. 21-39.
} 
ними жолобками, округлим і зубчатим штампом. Формувальна маса груба 3 домішками жорстви та кварцового піску, у перетині однорідного чорного кольору. Зовнішня поверхня коричневого та сірого кольору; внутрішня - темно-сірого, чорного та темно-коричневого кольору.

Корчаги складають третю, за кількістю фрагментів, групу (5\%). Серед них зустрічаються фрагменти корчаг з дугоподібною та прямою шийкою, максимальним діаметром розширення тулуба у верхній і середній частині тулуба (одна корчага мала вертикальні ручки, інша - орнаментована овальним вдавлюванням). Формувальна маса груба з домішками жорстви та кварцового піску, у перетині однорідного чорного або сірого кольору. Зовнішня поверхня коричневого або сірого кольору; внутрішня темно-сірого, чорного та темно-коричневого кольору.

Найменшу кількість фрагментів серед посудин закритого типу складають банкоподібні посудини $(1,5 \%)$ та черпаки $(1,5 \%)$.

Банкоподібні посудини представлені двома типами: з наміченою та прямою шийкою. Частина фрагментів орнаментована пружками. Формувальна маса груба 3 домішками жорстви та кварцового піску, у перетині однорідного чорного або сірого кольору. Зовнішня поверхня темно-коричневого, світло-коричневого кольору; внутрішня - темно-сірого та темно-коричневого кольору.

Черпаки з дугоподібною шийкою, максимальним розширенням у верхній третині тулуба. Формувальна маса лощена з домішками жорстви, у перетині однорідного сірого або чорного кольору. Зовнішня поверхня сірого, або темно-коричневого кольору; внутрішня - темно-сірого, чорного та темно-коричневого кольору.

Відкриті посудини репрезентовані мисками (78\%) та пласкими жаровнями (22\%) (таблиця 1). Миски - 3 прямими відігнутими стінками, пласким денцем великого діаметру. Вінчики заокруглені, переважно орнаментовані (по вінцю овальні й округлі вдавлювання). Формувальна маса груба з домішками жорстви та кварцового піску, у перетині однорідного світло-коричневого кольору. Зовнішня поверхня світлокоричневого кольору, пропечена; внутрішня - світло-коричневого кольору, пропечена.

Жаровні пласкі, округлі, частина - із сегментно-обрізаним корпусом, частина фрагментів має бортик по зовнішньому контуру. Формувальна маса груба з домішками жорстви та кварцового піску, у перетині однорідного світло-коричневого кольору. Зовнішня поверхня світло-коричневого кольору, пропечена; внутрішня - темно-сірого та світло-коричневого кольору, пропечена.

У посудин, переважно, груба формувальна маса, лощений посуд представлено тільки 25 (10 у заповнені та 15 в ямах) фрагментами закритих посудин (горщиків і кубків), що складає 10,8\% від загальної кількості посудин (232 фрагмента).

Основні групи та види посуду з приміщення № 21 характерні для посуду городища Дикий Сад ${ }^{8}$

Такий посуд трапляється у матеріалах поселень білозерського часу ПівнічноЗахідного Причорномор'я9.

Інші артефакти представлені виробами з рогу, кісток тварин, глини та каміння (таблиця 1). Серед них переважають псалії з рогу (враховуючи заготовки), кам'яні куранти та розтирачі.

\footnotetext{
8 Горбенко К.В. Посуд ділянки «Цитадель» городища Дикий Сад // Археологія. 2018. № 4. С. 27-45.

9 Ванчугов В.П. Белозерская культура в Северо-Западном Причерноморье. Проблема формирования белозерской культуры. Киев: Наук. думка, 1990. С. 59-81.
} 
Окремо треба виділити кам'яні предмети антропоморфної форми, що зафіксовано на рівні підлоги приміщення (рис. 9: 13,14 ) та у заповнені ям № $5,11,12$, 14 (рис. 10: 12, 17, 23, 24, 25). Це може вказувати на проведення певних ритуальних дій.

Екофакти складаються із залишків кісток і рогу тварин, астрагалів, кісток риби та панцирів черепах (таблиця 1).

Враховуючи наведені факти, можливо допустити, що у приміщенні № 21 проживала велика родина (наявність чоловічого та жіночого інвентарю), яка займалася виготовленням предметів з рогу та кісток тварин, керамічним виробництвом, ткацтвом і рибним промислом.

\section{REFERENCES}

Berezanskaia, S.S., Otroshchenko, V.V., Cherednichenko, N.N. \& Sharafutdinova, I.N. (1986). Kultury epokhi bronzy na territorii Ukrainy [Bronze Age Cultures at the territory of Ukraine]. Kiev [in Russian].

Cherniakov, I.T. (2010). «Dykyi Sad», Homer, Herodot, Troia, akheitsi ta kimmeriitsi (komentar odnoho arkheolohichnoho vidkryttia v Ukraini] [Dykyi Sad, Homer, Herodotus, Troy, Achaeans and Cimmerians (commentary on one archaeological discovery in Ukraine)]. Pratsi tsentru pamiatkoznavstva, 17, 116-122 [in Ukrainian].

Gorbenko, K.V. (2016). Osnovnye aspekty materialnoi kultury gorodishcha Dikiy Sad [The Main Aspects of the Material Culture of the Hillfort Dikiy Sad]. Eminak, 4 (16), 19-32 [in Russian].

Gorbenko, K.V. (2017). Nachalnyi etap arkheologicheskikh issledovanii gorodishcha Dikiy Sad [The initial stage of archaeological researches of the hillfort Dikiy Sad]. Eminak, 3 (19), Vol. 2, 9-25 [in Russian].

Horbenko, K.V. (2018). Posud dilianky «Tsytadel» horodyshcha Dykyi Sad [The pottery of the «citadel» site of Dykyi Sad hillfort]. Arkheolohiia, 4, 27-45 [in Ukrainian].

Horbenko, K.V. (2018). Ukriplene poselennia (horodyshche) epokhy finalnoi bronzy Dykyi Sad u misti Mykolaevi [Fortified settlement (hillfort) of the era of the Final Bronze Age Dykyi Sad, Mykolaiv]. Kraeznavstvo, 1 (102), 6-20 [in Ukrainian].

Horbenko, K.V. \& Hoshko, T.Yu. (2010). Metalevi vyroby z poselennia Dykyi Sad [Metal products from Dykyi Sad]. Arkheolohiia, 1, 97-111 [in Ukrainian].

Horbenko, K.V. \& Pashkevych, H.o. (2010). Paleoetnobotanichni doslidzhennia na terytoriyi horodyshcha Dykyi Sad [Palaeobotanic researches on the territory of the hillfort Dykyi Sad]. Eminak, 14 (5), 5-19 [in Ukrainian].

Hoshko, T.Yu., Ahapov, S.O. \& Otroshchenko, V.V. (2018). Metalevi kazany z Velykoho Stepu za doby piznoi bronzy [Late Bronze Age metal cauldrons from the Great Steppe]. Kyiv [in Ukrainian].

Otroshchenko, V.V. (2008). Ukriplene poselennia «Dykyi Sad» v systemi pamiatok bilozerskoi kultury [Fortified settlement Dikij Sad in system of monuments of Belozerskaia's culture]. Eminak, 1-4 (3), 510 [in Ukrainian].

Vanchugov, V.P. (1990). Belozerskaia kultura v Severo-Zapadnom Prichernomorie. Problema formirovaniia belozerskoi kultury [Belozerskaia culture in the North-Western Black Sea region. The problem of the forming of Belozerskaia culture]. Kiev [in Russian].

\section{Kyrylo Horbenko}

(Mykolayiv National University named after V. Sukhomlinsky, Mykolayiv, Ukraine)

ORCID: https://orcid.org/0000-0002-0510-3792

\section{Oleksandr Smyrnov}

(Mykolayiv National University named after V. Sukhomlinsky, Mykolayiv, Ukraine)

ORCID: https://orcid.org/0000-0002-7849-3840

\section{Constructional Features and Character of Structure № 21 of Ancient Settlement Dykyi Sad}

The paper reveals the architectural features of the structure № 21 of the ancient settlement Dykyi Sad (Wild Garden), determines the nature of the internal filling of the pits, ana- 
lyzes material objects (ceramic pottery, objects made of clay, stone, horn, and bronze). The structure was located along the defense moat of the «citadel», adjacent to the western part to the structure № 13 , and was oriented almost to the cardinal points $(9,0 \times 7,0 \mathrm{~m}$ with a deepening $0,4-0,5 \mathrm{~m}$ to the subsoil). The walls of the structure were wattle and daub mixed with medium and fine limestone. The southern wall was made of big pieces of limestone (in the eastern part it was a basement, in the western part it was coated). It should be noted separately that in the structure's filling (floor level) the large number (more than 100 fragments) of tool marked horns of deer, goats, and saigas were found.

At the floor level of the structure, 22 pits for different purposes (pole, utility, utility and production, utility and ritual) were found.

A special place in the research takes the analysis of the assemblage of material objects. Among plates and dishes predominate closed pottery (pots of different types, jar-like pots, goblets, bailers and large earthenware pots (korchagas)) with a variety of ornaments. Open dishes are represented with bowls and flat roasters. It is ascertained that such pottery was found in the materials of settlements of the Belozersk period of the North-Western Black Sea.

Other artifacts are represented with produced items made of horn, animal bones, clay and stone (cheek-pieces made of horn, stone pestles and grinders, stone objects of the anthropomorphic form).

It is noted that the constructional features of the structure, the nature of the pits, the found artifacts and ecofacts, allow assuming that the structure № 21 was a utility and production workshop with a complex system of multifunctional pits. Such buildings were typical for the sites of the North-Western Black Sea region of the Late and Final Bronze Age.

Keywords: Final Bronze Age, ancient settlement Dykyi Sad, Belozersk Culture, material objects, artifacts 
Таблиця 1. Статистика знахідок з приміщення № 21 (заповнення та ями)

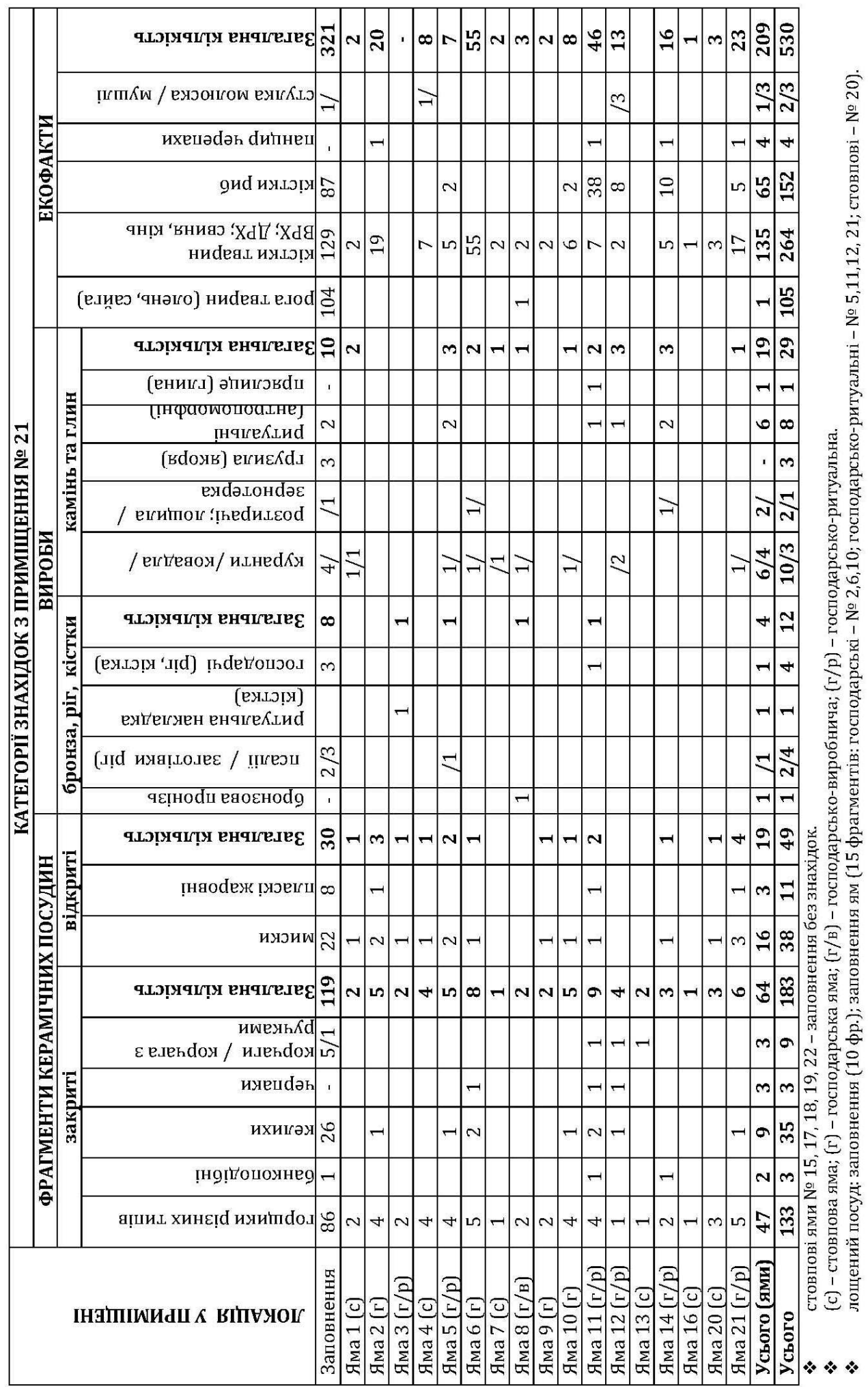




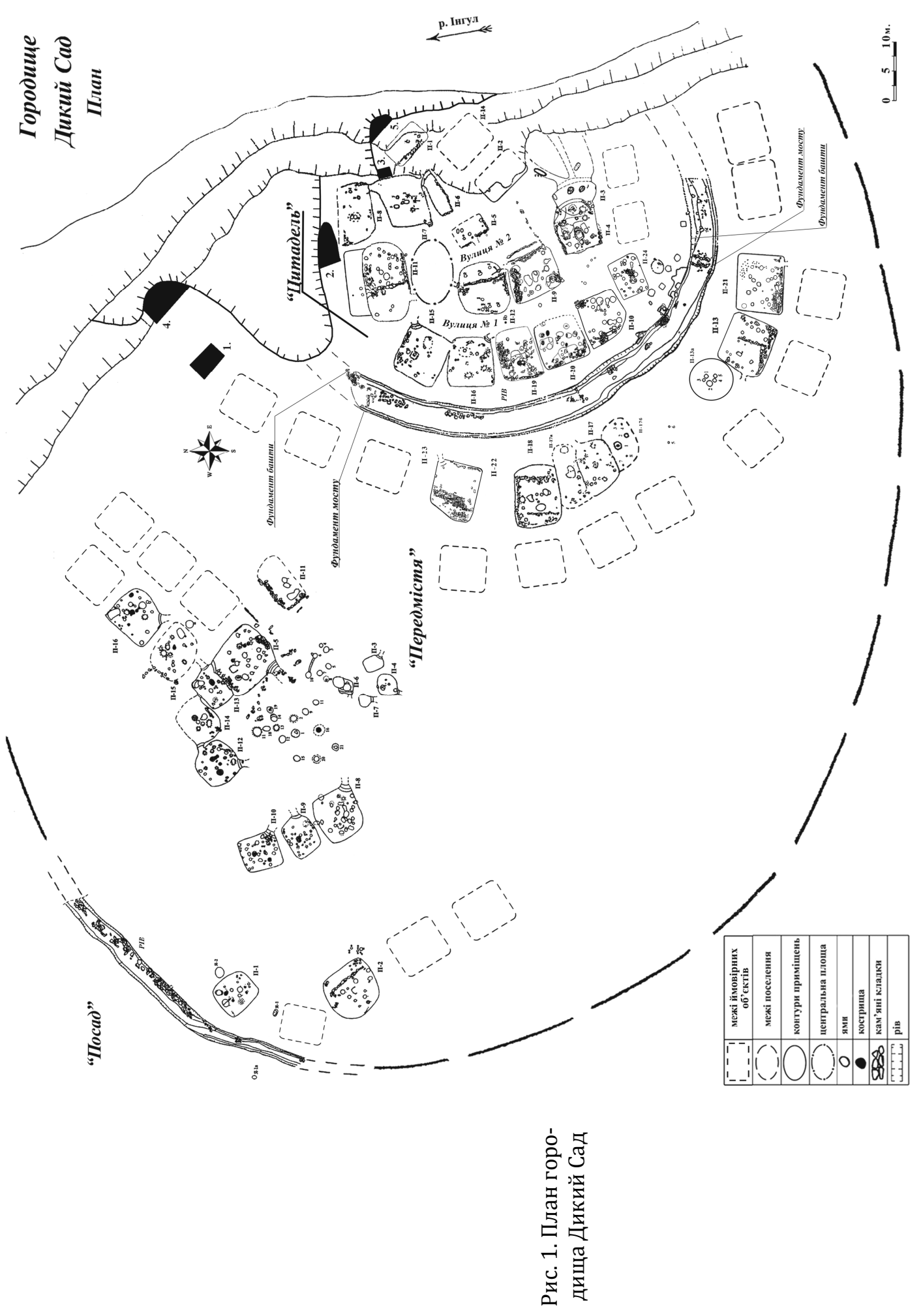


ПI-21
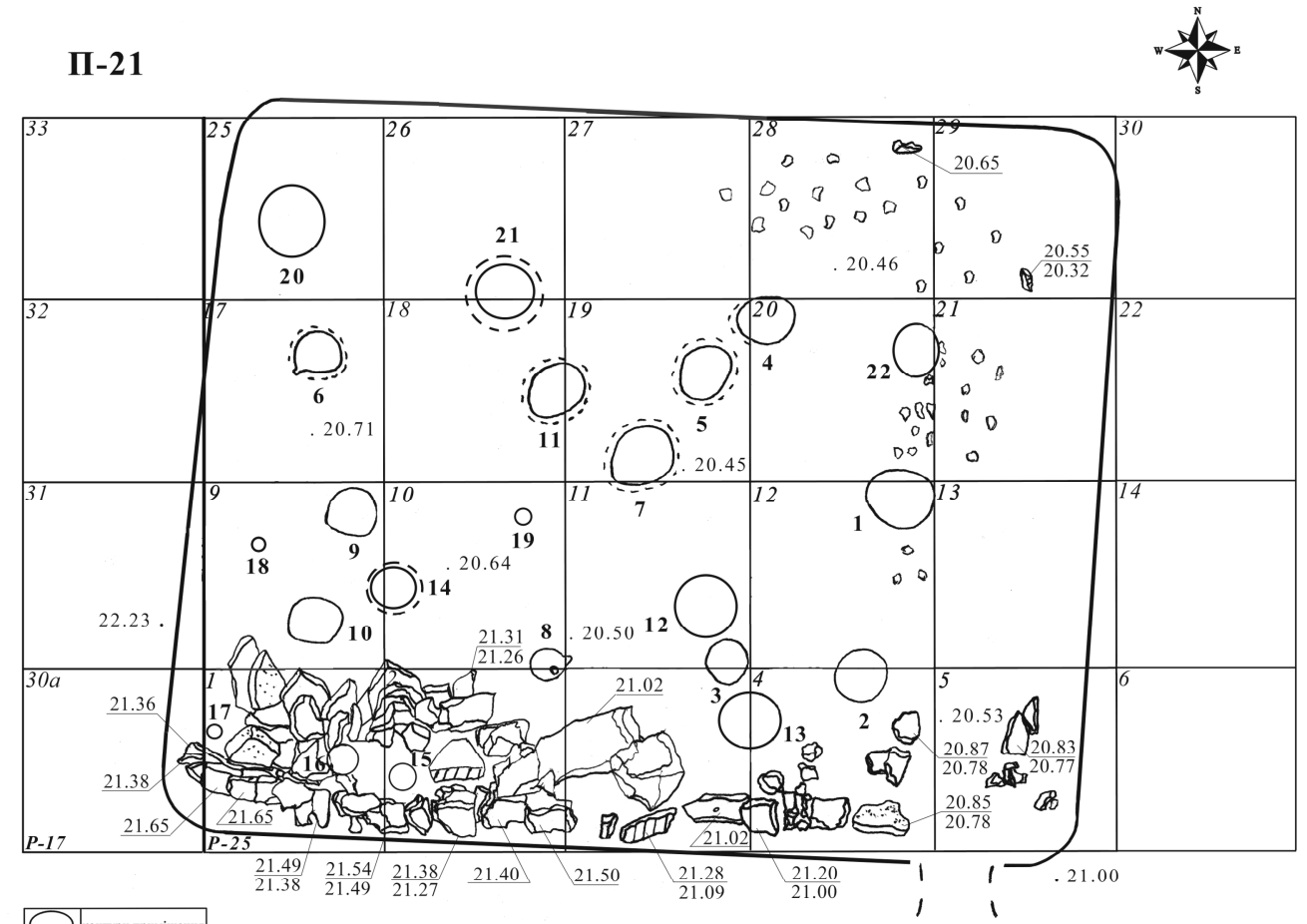

\begin{tabular}{|c|c|}
\hline & контури приміщения \\
\hline 0 & ями \\
\hline E\&8 & кам'яні кладки \\
\hline
\end{tabular}

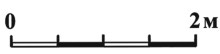

Рис. 2. План приміщення № 21
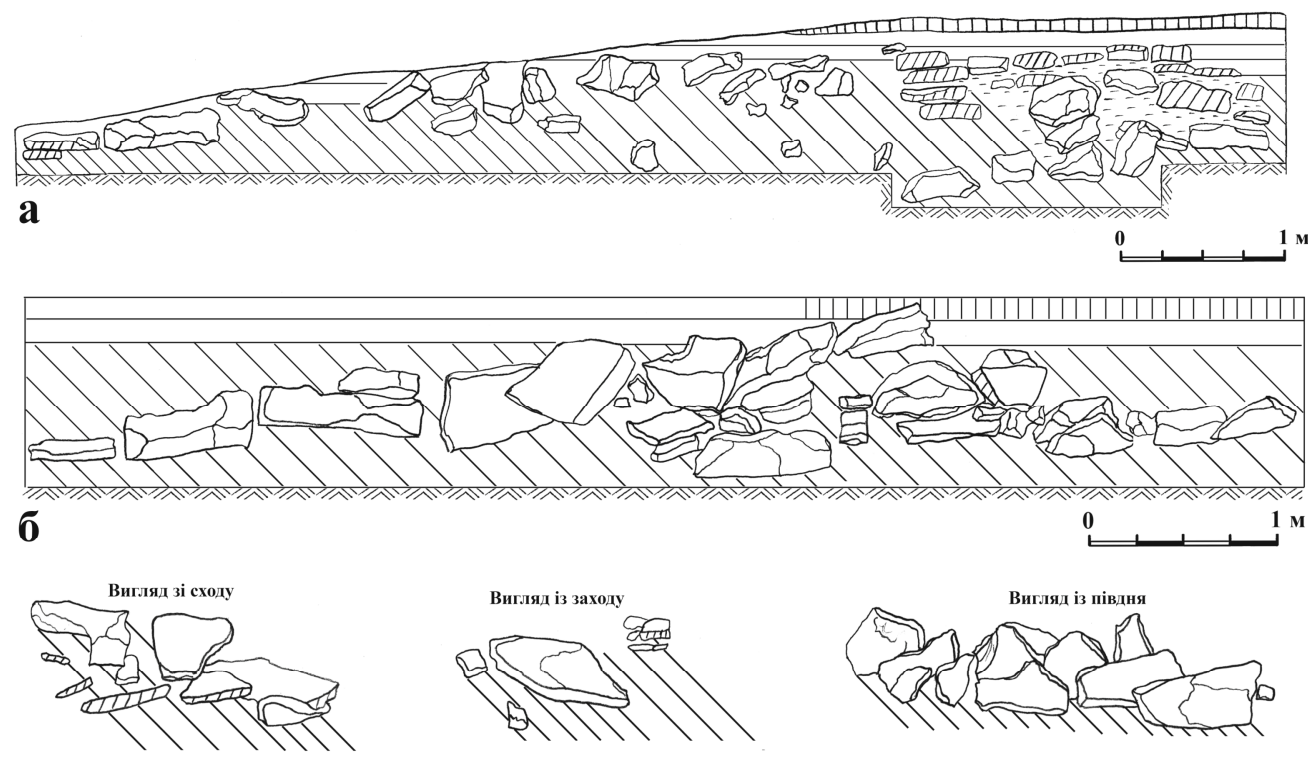

B

Ш - підсипка під дорогу 20-го століття

园-гумус

$\nabla$ - світло-коричневий суглинок

$\square$ - глинисто-земляний розчин

"ベ- материк

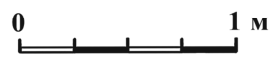

Рис. 3. Кам’яна кладка південної стіни приміщення № 21 (північний профіль) а. перший ряд кладки

б. другий ряд кладки

в. кам'яна прибудова в західній частині стіни (кв. 1-2): західний, східний і північний борт 
1

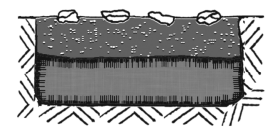

2

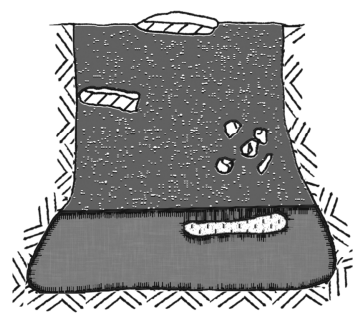

9

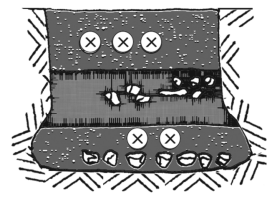

3

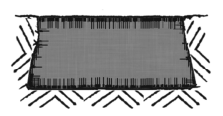

6

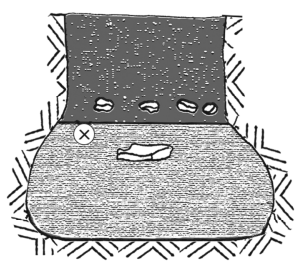

10

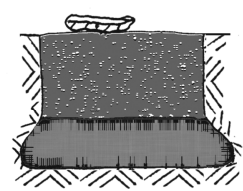

4

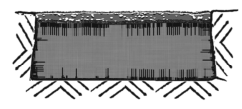

7

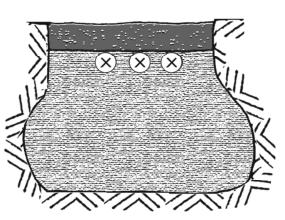

11

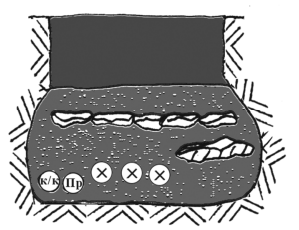

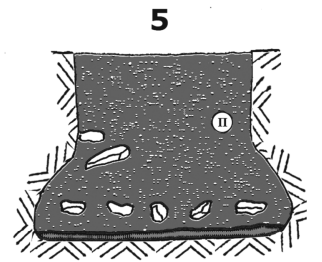

8

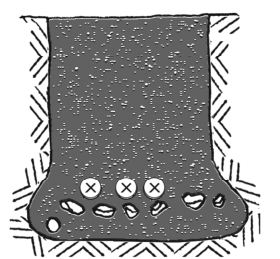

12

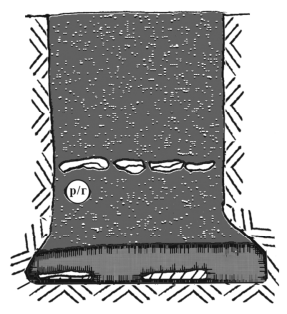

- суглинок золистого кольору

$$
\begin{aligned}
& \text { ()- фрагмент кераміки } \\
& \text { II) - псалій } \\
& \text { II) - прясельце } \\
& \text { p/r) - розвал горщика } \\
& \text { К/к) - кістяна котушка }
\end{aligned}
$$

0

$1 \mathbf{M}$
13

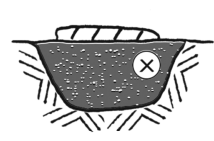

19

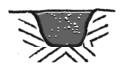

14

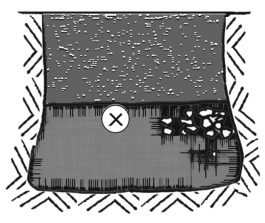

20

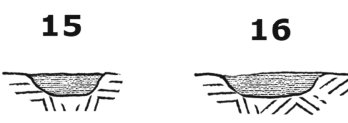

21

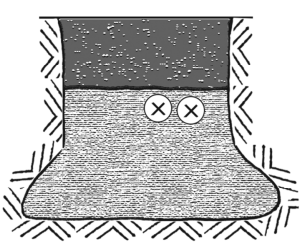

22

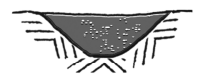

Рис. 4. Розрізи ям приміщення 

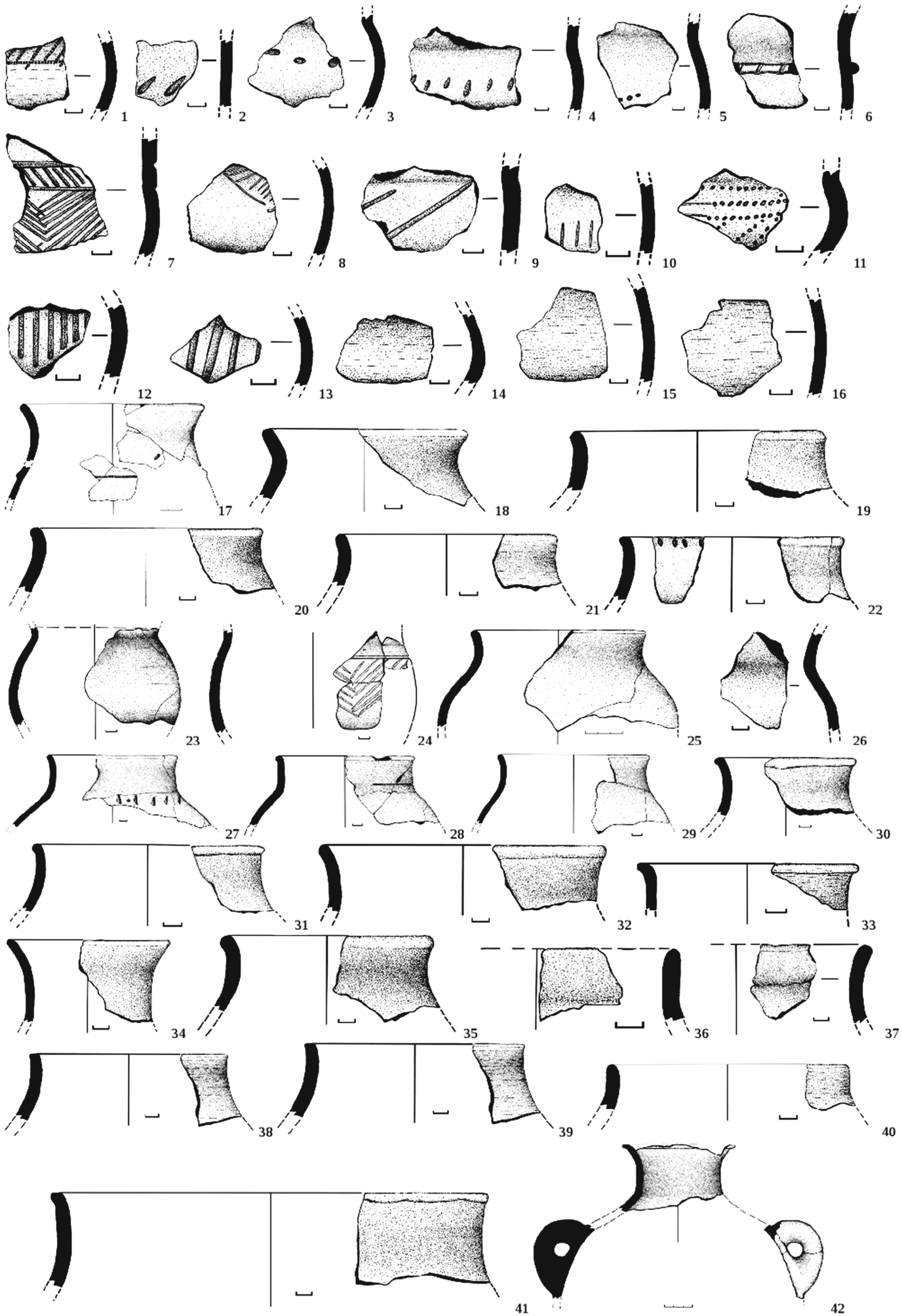

Рис. 5. Керамічний посуд з заповнення приміщення № 21 (закриті посудини) горщики $(2,4-7,9,17,18,20-32,35,38,40)$; банкоподібні $(36)$; келихи $(1,3,8,10-16,33,34)$; корчаги $(19,32,37,39,41)$; корчага з ручками $(42)$ 

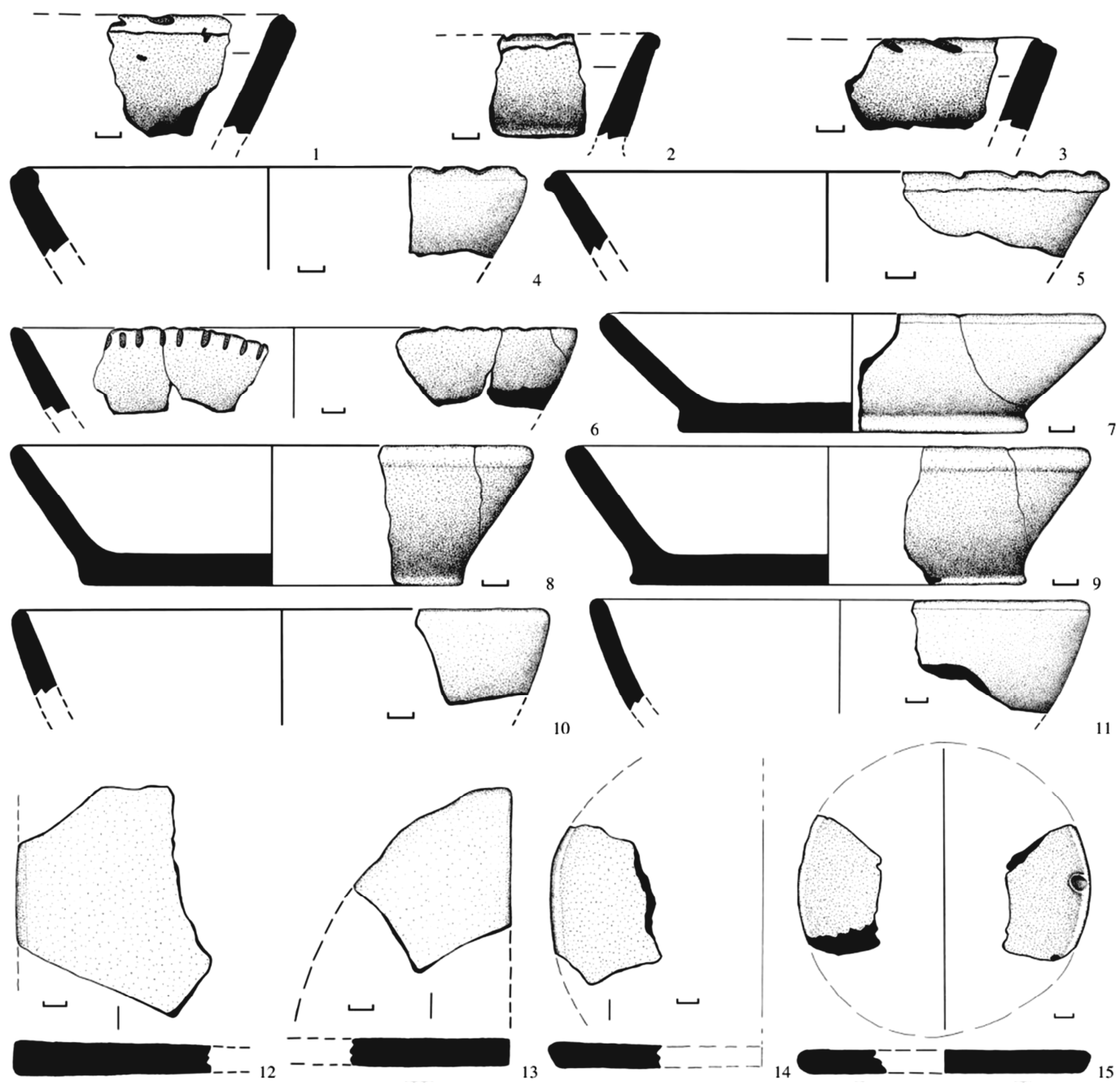

Рис. 6. Керамічний посуд з заповнення приміщення № 21 (відкриті посудини) миски (1-11); пласкі жаровні (12-15) 

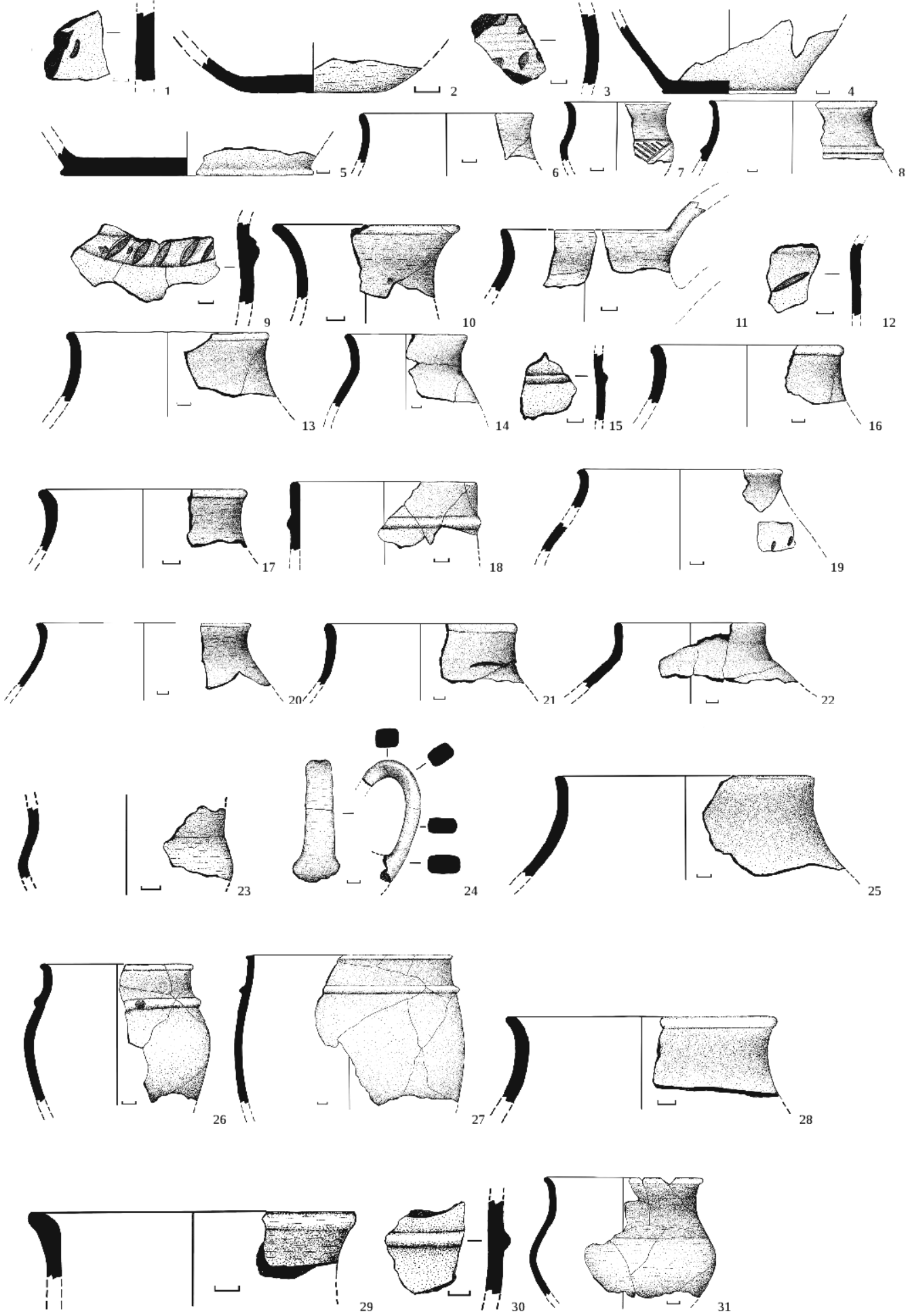

Рис. 7. Керамічний посуд з заповнення ям приміщення № 21 (закриті посудини)

Яма № 1 (1); Яма № 2 (2, 3); Яма № 3 (4); Яма № 5 (5, 6); Яма № 6 (7-11); Яма № 7 (12); Яма № 9 (13); Яма № 10 (14-15); Яма № 11 (16-20); Яма № 12 (21-24); Яма № 13 (25); Яма № 14 (26-27); Яма № 21 (28-31).

горщики $(1,3,4,5,8,9,12,13,15,16,20,21,26,28,29,30)$; банкоподібні $(18,27) ;$ келихи $(2,6,7,10$, $14,17,23,31)$; черпаки $(11,24) ;$ корчаги $(19,22,25)$ 

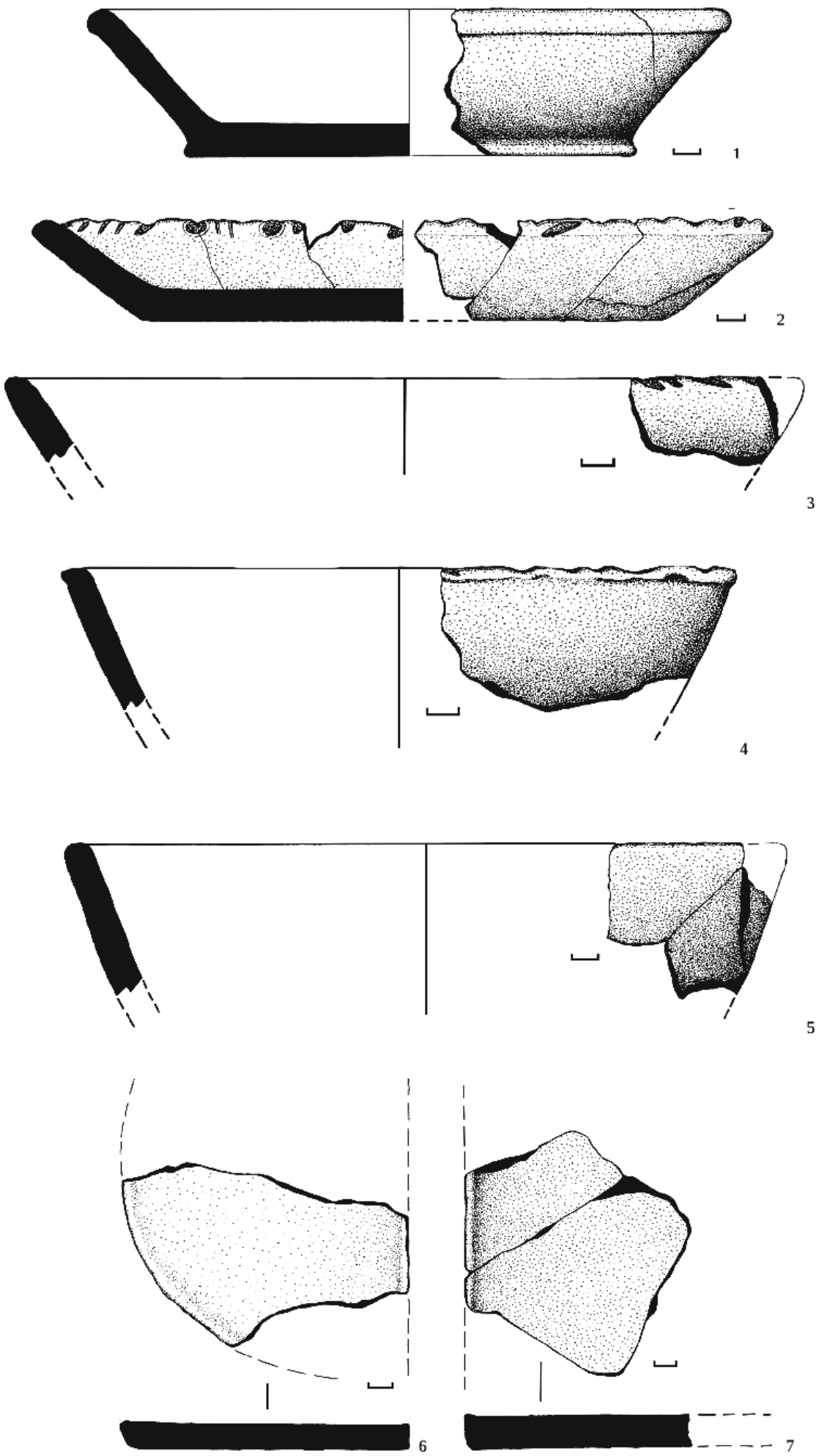

Рис. 8. Керамічний посуд з заповнення ям приміщення № 21 (відкриті посудини) Яма № 2 (6); Яма № 11 (1); Яма № 14 (2); Яма № 21 (3-5, 7). миски (1-5); пласкі жаровні (6-7) 

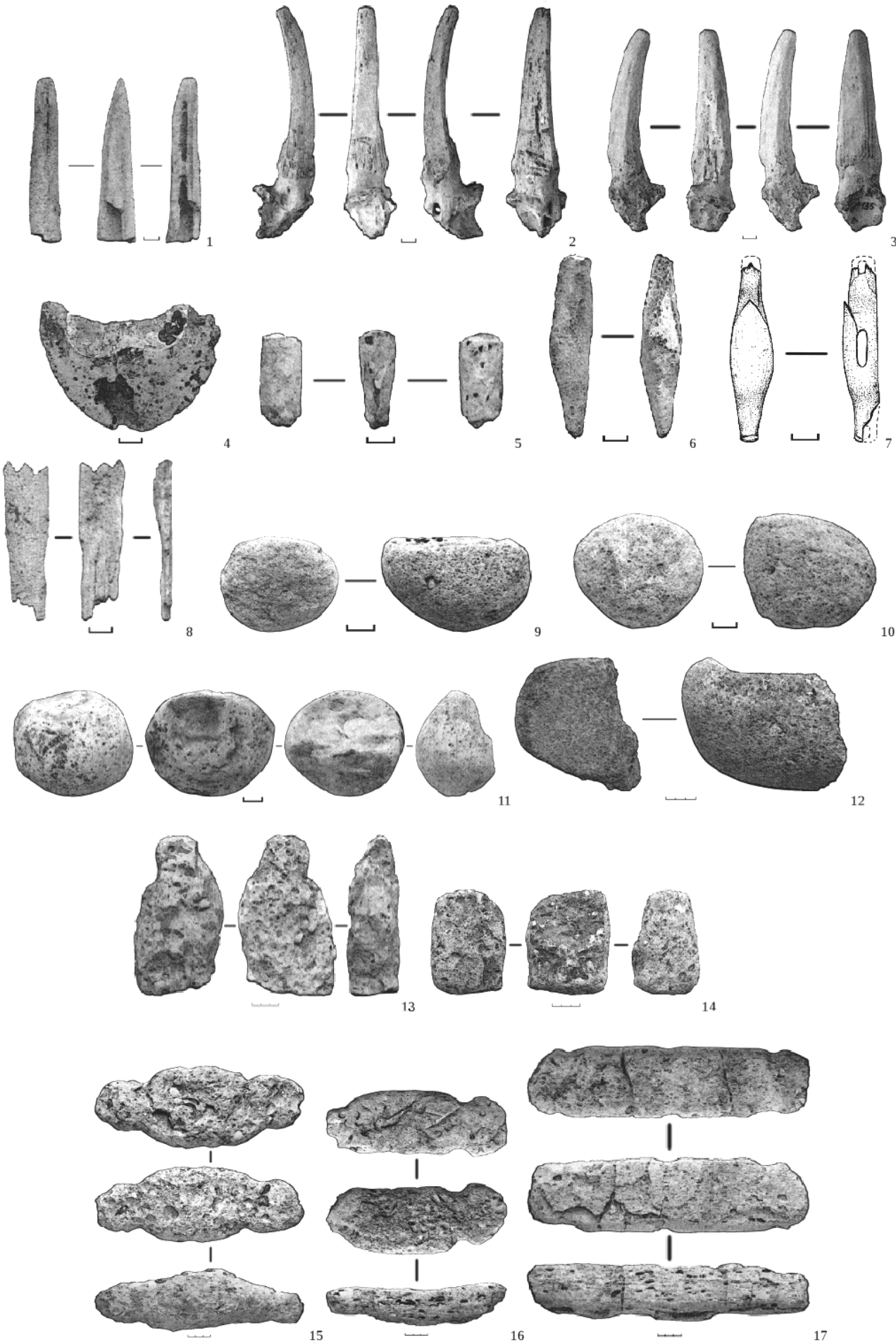

Рис. 9. Предмети з каменю, кістки та рогу з заповнення приміщення № 21

1: ріг (фрагмент гарпуна); 4: копито коня (лощило); 2,3,5,6: ріг сайги (заготівки для псаліїв); 7: ріг сайги (псалій з трьома отворами); 8: кістяний предмет для нанесення орнаменту; 9,10,11:кам'яні знаряддя (куранти); 12: кам'яна зернотерка; 13,14: кам'яні антропоморфні предмети; 15,16,17 кам'янігрузила (якоря) 

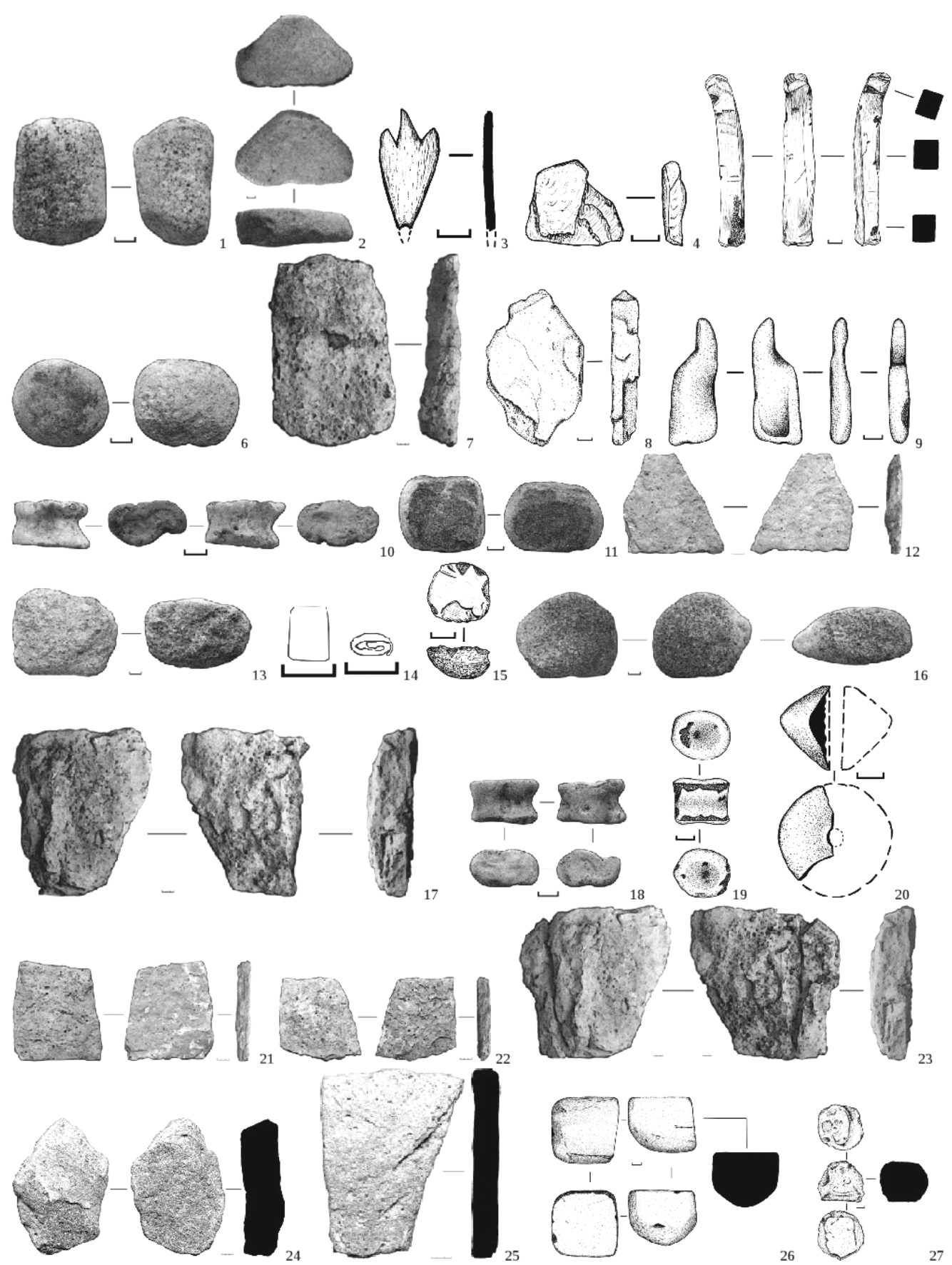

Рис. 10. Предмети з каменю, кістки, рогу, глини та бронзи з заповнення ям приміщення № 21 Яма № 1 (1); Яма № 2 (2); Яма № 3 (3, 4); Яма № 5 (5-8); Яма № 6 (9-11); Яма № 7 (12); Яма № 8 $(13,14) ;$ Яма № 9 (15); Яма № 10 (16); Яма № 11 (17-20, 23); Яма № 12 (21, 22, 23); Яма № 14 (24-26); Яма № 21 (27). 1: кам'яний товкач; 2: кам'янековадло; 3: предмет з кістки тварини (ритуальна накладка); 4: кам'яний предмет пласкої форми -відщеп (квари); 5: заготівка для псалія (ріг сайги); 6: кам'яний предмет (курант); 7,8: кам'яні предмети антропоморфної форми; 9: кам'яний предмет (лощило для виробів з кісткита рогу?); 10,18: астрагали; 11,26: кам'яні предмети (розтирачі); 12: пласка плитка антропоморфної форми (?); 21,22: пласкі кам'яні плитки (ковадла); 13,16,27: кам'яні предмети (куранти); 14: бронзова пронізь (фрагмент прикраси); 15: кремінь; 17,23,24,25: кам'яні антропоморфні стели; 19: виріб з хребия тварини (котушка); 20: фрагмент керамічного пряслиця 